\title{
Comparison of Selected Chemical Properties of Peat Swamp Soil Before and After Timber Harvesting
}

\author{
${ }^{1}$ Muhamad Ismawi Salimin, ${ }^{1}$ Seca Gandaseca, \\ ${ }^{2}$ Osumanu Haruna Ahmed and ${ }^{1}$ Nik Muhamad Ab. Majid \\ ${ }^{1}$ Department of Forestry Science, \\ ${ }^{2}$ Department of Crop Science, \\ Faculty of Agriculture and Food Sciences, University Putra Malaysia, \\ Bintulu Campus, Sarawak, 97008 Bintulu, Sarawak, Malaysia
}

\begin{abstract}
Problem statement: Peat swamp is an important component of the world's wetlands. Once they are disturbed the tendency for the soil degradation is very high. This study compared selected chemical properties of a peat swamp soil before and after timber harvesting. Approach: Peat soil samples were taken at 0-15 cm depth in 6 plots with 0.1 ha each plot at Batang Igan forest at Sibu Sarawak, Malaysia. The soil samples were analyzed for selected soil chemical properties. Data were analyzed by using Statistical Analysis System (SAS) version 9.2. Results: The tropical peat swamp forest indicate its specific natural state such as rich in soil $\mathrm{pH} \mathrm{KCl}$ and except for $\mathrm{C} / \mathrm{N}$ ratio, the selected chemical properties such as soil $\mathrm{pH}$ water, cation exchange capacity, soil organic matter, total carbon, total nitrogen, total phosphorus and exchangeable potassium were significantly different between before and after timber harvesting. Conclusion: Timber harvesting has significant effect on chemical properties of peat swamp.
\end{abstract}

Key words: Peat swamp forest, soil acidity, cation exchange capacity, soil organic matter, total carbon, total nitrogen, total phosphorus, exchangeable $\mathrm{K}$ and $\mathrm{C} / \mathrm{N}$ ratio

\section{INTRODUCTION}

Peat soil is defined as the accumulation of $100 \%$ pure organic material. Peat is an organic soil that contains at least $65 \%$ organic matter or less than $35 \%$ mineral content. Peat soil also can be classified based on profile partition where out of $100 \mathrm{~cm}$ there are 50 $\mathrm{cm}$ of organic soil matter or more than twice or mineral soil material is twice which overlay on bedrock within $50 \mathrm{~cm}$. A soil is also considered to be peat if the organic soil is more than half of the upper soil or if organic soil material is deposited on rock or having filled up with organic materials (Mohamed et al., 2002).

Peat soils also called organic soils which are formed in the surface layers. They occur in three geomorphic situations, lowland coastal swamps, inland swamps and valleys and high altitude which are free draining situations and highland swamps. Peat swamps are part of fragile environment threatened by land development like agricultural and urban, logging such as unsustainable logging practices and over harvesting of commercial species, fire which is deliberate or accidental and alteration of the hydrology by the construction of dams for oil pipelines. Most peat swamps are generally elevated 4-9 $\mathrm{m}$ above the adjacent river courses and the surface slopes vary gently between 1-2 $\mathrm{m} \mathrm{km}^{-1}$ (Andriesse, 1988).

Peat soils are classified as highly organic soft soil that mainly composed of fibrous organic matters such as leaves and stem which are partly decomposed. Peat mainly consists of large plants residues that are decomposed through lack of oxygen condition (Deboucha et al., 2008). The objective of this study was to compare the soil $\mathrm{pH}$, cation exchange capacity, soil organic matter, total carbon, total nitrogen, total phosphorus and exchangeable $\mathrm{K}$ of peat swamps soil, before and after harvesting at Batang Igan forest in Sibu, Sarawak.

\section{MATERIALS AND METHODS}

Peat soil samples were taken at $0-15 \mathrm{~cm}$ depth in 6 plots with 0.1 ha each plot at Batang Igan Sibu, Sarawak, Malaysia. The soil $\mathrm{pH}$ was determined by the method outlined by Matthiesen (2004).

Corresponding Author: Seca Gandaseca, Department of Forestry Science, Faculty of Agriculture and Food Sciences, University Putra Malaysia Bintulu Campus, Sarawak, 97008 Bintulu, Sarawak, Malaysia Tel: +6086855473 Fax: +6086855416 
Am. J. Environ. Sci., 6 (2): 165-167, 2010

Table 1: Selected soil chemical properties before and after timber harvesting of tropical peat swamp forest

\begin{tabular}{|c|c|c|}
\hline \multirow[b]{2}{*}{ Variable } & \multicolumn{2}{|l|}{ Means } \\
\hline & Before & After \\
\hline $\mathrm{pH}-\mathrm{KCl}$ & $3.71 \pm 0.04^{\mathrm{a}}$ & $3.73 \pm 0.03^{\mathrm{a}}$ \\
\hline pH-Water & $3.25 \pm 0.01^{\mathrm{a}}$ & $3.43 \pm 0.02^{\mathrm{b}}$ \\
\hline CEC (meq 100g ${ }^{-1}$ ) & $68.04 \pm 1.99^{\mathrm{a}}$ & $46.17 \pm 1.36^{\mathrm{b}}$ \\
\hline SOM (\%) & $97.69 \pm 0.91^{\mathrm{a}}$ & $96.59 \pm 1.42^{\mathrm{b}}$ \\
\hline Total C (\%) & $48.85 \pm 0.09^{\mathrm{a}}$ & $48.30 \pm 0.14^{\mathrm{b}}$ \\
\hline Total N (\%) & $0.79 \pm 0.06^{\mathrm{a}}$ & $1.18 \pm 0.11^{\mathrm{b}}$ \\
\hline Total P $\left(\mathrm{mg} \mathrm{L}^{-1}\right)$ & $219.20 \pm 18.79^{\mathrm{a}}$ & $312.00 \pm 34.98^{\mathrm{b}}$ \\
\hline Exchangeable $\mathrm{K}\left(\mathrm{mg} \mathrm{L}^{-1}\right)$ & $330.60 \pm 20.66^{\mathrm{a}}$ & $613.90 \pm 42.92^{\mathrm{b}}$ \\
\hline $\mathrm{C}: \mathrm{N}$ ratio & $74.04 \pm 8.47^{\mathrm{a}}$ & $53.25 \pm 6.52^{\mathrm{a}}$ \\
\hline
\end{tabular}

Note: Means with different letters within column indicate significant difference between before and after timber harvesting by independent t-test at $\mathrm{p} \leq 0.05$

The loss on ignition method was used to determine soil organic matter and total C (Ben-Dor and Banin, 1989). Soil CEC and exchangeable $\mathrm{K}$ were determined by leaching method followed by steam distillation technique (Brady and Weil, 2008). After extraction, the exchangeable $\mathrm{K}$ was measured using atomic absorption spectrophotometry (Analyst 800, Perkin Elmer Instruments, Norwalk, CT). Total nitrogen was determined by the Kjeldahl method (Jones, 2001). The total phosphorus was extracted by the aqua regia method and its concentration measured by the colorimetric determination method. These selected soil chemical properties before and after timber harvesting were analyzed statistically using Statistical Analysis System (SAS) version 9.2.

\section{RESULTS}

According to Table 1 , the soil $\mathrm{pH}(\mathrm{KCl})$ showed that there was no significant difference between before and after timber harvesting, but the soil $\mathrm{pH}$ in water showed that there was significant difference between before and after timber harvesting. There were significant differences between the Cation Exchange Capacity (CEC), soil Organic Matter (OM), total Carbon (C), total N, total P, exchangeable $\mathrm{K}$ of before and after timber harvesting. However, there was no significant difference between the $\mathrm{C} / \mathrm{N}$ of before and after timber harvesting.

\section{DISCUSSION}

Soil acidity is one of the chemical properties of soil. It is important in order to determine fertility of the soil and related to other nutrients and also other chemical properties. Compared to soil $\mathrm{pH}$ in water, there was significant difference before $(3.25 \pm 0.01)$ and after (3.43 \pm 0.02$)$ timber harvesting. This was because $\mathrm{pH}$ water indicates the current soil $\mathrm{pH}$ during sampling while $\mathrm{pH} \mathrm{KCl}$ indicates the condition of soil $\mathrm{pH}$ in long term. The range of soil $\mathrm{pH}$ before and after was typical of $\mathrm{pH}$ of organic soils. As reported by Mohamed et al. (2002) organic soils in Sarawak are very acidic soils with $\mathrm{pH}$ ranging from 3.2-4.0.

Cation Exchange Capacity (CEC) is pH dependent (Tie, 1988), has pointed out that the standard value of CEC for peat soil was in range of 40-135 meq $100 \mathrm{~g}^{-1}$. As the $\mathrm{pH}$ increases, the CEC also increases and vice versa. This study showed that timber harvesting has significant influence on the CEC as the mean before harvesting was $68.04 \pm 1.99$ meq $100 \mathrm{~g}^{-1}$ and $46.17 \pm 1.36$ meq $100 \mathrm{~g}^{-1}$ after harvesting. There was a slight change of soil $\mathrm{pH}$ after timber harvesting and this affected the CEC as the CEC after harvesting was lower than before harvesting. The CEC decreased as $\mathrm{pH}$ decreased because of low base saturation of organic soils in Sarawak which highly saturated with hydrogen ions (Tie and Kueh, 1979).

Soil organic matter influences many of the chemical, physical and biological properties of the soil. The decomposition rates of SOM affect properties of soils. It depends on the amount of organic matter available and rate of decomposition. In this study timber harvesting reduced SOM from 97.69 \pm 0.91 $96.59 \pm 1.42 \%$.

According to Tie and Lim (1991), most of the organic soils in Sarawak in their natural state, show very little difference in terms of the degree of decomposition of the organic material.

This present study showed that total carbon of the peat soil forest changed before and after timber harvesting. Total carbon declined from $48.85 \pm 0.095-$ $48.30 \pm 0.14 \%$ after timber harvesting. Eswaran et al. (1993) and Brady and Weil (2008) reported that total carbon range for peat soil is $12.0-57.0 \%$. The total carbon is related to the soil organic matter. After harvesting, organic matter of the soil decreased because of no input of organic matter from plants due to harvesting.

Similar as reported by Nye and Greenland (1960) and Cunningham (1963), soil organic matter declines rapidly after soil is exposed due to clearing activities. Soil organic matter begins to decline as soil temperature increases when exposed to sunlight due to loss of canopy cover and shifts the equilibrium between accumulation and decomposition. When this condition occurs, decomposition rate will increase because of rapid activities of soil microorganism as the environment was favorable to them. Rapid 
decomposition makes the carbon most utilized by microorganism and consequently change the value of total carbon in the peat soil.

Total $\mathrm{N}$ after the timber harvesting was higher, compared to that of before timber harvesting. After logging activities, the water table decreased. This condition promotes more oxygen in the soil space and hence increases decomposition rate.

The nitrogen of this peat swamp forest was found to be within the range of shallow peat (Mohamed et al., 2002). This also indicates that our research site had a very low mineral nitrogen $\left(\mathrm{NH}_{4}{ }^{+}\right.$or $\left.\mathrm{NO}_{3}^{-}\right)$which is important for plant growth (Brady and Weil, 2008). However, in strongly acidic and anaerobic or flooded soil, the population of nitrifying bacteria is usually low or absent. Hence, the amount of ammonium-N in this soil was considerably greater than that of nitrate- $\mathrm{N}$ because of the low nitrification activity (Juo and Franzluebbers, 2003). Furthermore, the low amount of nitrogen in peat surface is sensitive to water table level.

Total phosphorus of the soil in peat swamp forest showed a significant changed before and after timber harvesting. Total $\mathrm{P}$ after and before timber harvesting were $312.00 \pm 34.98$ and $219.20 \pm 18.79 \mathrm{mg} \mathrm{L}^{-1}$, respectively. The result shows that total $\mathrm{P}$ was lower compared to the standard range in Sarawak (400$1000 \mathrm{mg} \mathrm{L}^{-1}$ ) Andriesse (1988).

This present study showed that the exchangeable $\mathrm{K}$ in the soil was significantly different for before and after timber harvesting. The increase of exchangeable $\mathrm{K}$ in the soil after logging was due to rapid decomposition of organic matter.

Referring to Brady and Weil (2008), soil pH has influence to the availability of potassium content in soil. The authors also stated that the annual loss of potassium by leaching is greater than usual in acid soils. When desiccation occurs, the soil aeration increases. Soil organisms activities also increase and this promotes rapid decomposition. Decomposition releases the inside organic matter into available form. As this condition prevails, more nutrients are available especially $\mathrm{K}$. However, the quantity of available $\mathrm{K}$ or held in an easily exchangeable condition at any one time is often very small.

$\mathrm{C} / \mathrm{N}$ ratio is an indication of the degree of humification of the organic materials (Andriesse, 1988). Generally $\mathrm{C} / \mathrm{N}$ ratio in peat soil is high. According to Katase et al. (1991) the standard C: $\mathrm{N}$ ratio in peat soil is $20.0-46.3 \%$. Timber harvesting had no influence on the C:N ratio. Based on the carbon and nitrogen contents before and after harvesting, there were significant differences in carbon and nitrogen content, however the significant differences between carbon and nitrogen content did not affect $\mathrm{C}: \mathrm{N}$ ratio. This was because the process of changes in $\mathrm{C}: \mathrm{N}$ ratio takes time to reflect.

\section{CONCLUSION}

Timber harvesting has significant effect on Cation Exchange Capacity (CEC), Soil Organic Matter (SOM), exchangeable $\mathrm{K}, \mathrm{pH}$ in KCL, total $\mathrm{C}, \mathrm{N}$ and $\mathrm{P}$ of peat swamp.

\section{ACKNOWLEDGEMENT}

Fund for this research was provided by the Ministry of Higher Education Malaysia. The authors also thank the Forest Department of Sarawak, Sarawak Forestry Corporation and New Time Resources Sdn. Bhd. for the permission and cooperation during the research.

\section{REFERENCES}

Andriesse, J.P., 1988. Nature and Management of Tropical Peats. FAO Soils Bulletin 59. FAO, Rome, ISBN: 92-5-102657-2, pp: 165.

Ben-Dor, E. and A. Banin, 1989. Determination of organic matter content in arid-zone soils using a simple "loss-on-ignition" method. Commun. Soil Sci. Plant Anal., 20: 1675-1695. DOI: 10.1080/00103628909368175

Brady, N.C. and R.R. Weil, 2008. The Nature and Properties of Soils. 14th Edn., Pearson Education, Inc, New Jersey, ISBN: 0135133874, pp: 504-517.

Cunningham, R.K., 1963. The effect of clearing a tropical forest soil. J. Soil Sci., 14: 334-345. DOI: 10.1111/j.1365-2389.1963.tb00957.x

Deboucha, S., R. Hashim and A. Alwi, 2008. Engineering properties of stabilized tropical peat soils. Elect. J. Geotech. Eng., 13: 1-9.

Eswaran, H.E., V.D. Berg and P. Reich, 1993. Organic carbon in soils of the world. Soil Sci. Soc. Am. J., 57: 192-194.

Jones, J.B., 2001. Laboratory Guide for Conducting Soil Tests and Plant Analysis. CRC Press, USA., ISBN: 0849302064, pp: 209-212.

Juo, A.S.R. and K. Franzluebbers, 2003. Tropical Soils: Properties and Management for Sustainable Agriculture. 1st Edn., Oxford University Press, Inc, New York, ISBN: 0195115988, pp: 88-91. 
Katase, T., S. Hirotya., M. Naoi., K. Yamamoto and H. Sumida et al., 1991. A Comparison of Phenolic Constituents In Peat Soils Between Subfrigid Area, Japan and Troypical areas of Peninsular Malaysia and Thailand, In: Tropical Peat, Aminuddin B.Y. (Ed.). MARDI, Malaysia, ISBN: 9679361276, pp: 57-65.

Matthiesen, H., 2004. In situ measurement of soil pH. J. Archaeolog. Sci., 31: 1373-1381. DOI: 10.1016/j.jas.2004.03.005

Mohamed, M., E. Padmanabhan, B.L.H. Meiand and W.B. Siong. 2002. The Peat Soils of Sarawak. University Malaysia Sarawak. Malaysia. http://www.strapeat.alterra.nl/download/12\%20pea t\%20soils\%20of\%20Sarawak.pdf

Nye, P.H. and D. Greenland, 1960. The Soil under Shifting Cultivation. Harpenden, England: Commonwealth Bureau of SoUs.
Tie, Y.L. and H.S. Kueh, 1979. A review of lowland organic soils of Sarawak. Department of Agriculture, Technical Paper 4, Research Branch, Sarawak, Malaysia. http://library.wur.nl/isric/index2.html?url=http://lib rary.wur.nl/WebQuery/isric/16904

Tie, Y.L. and J.S. Lim, 1991. Characteristics and Classification of Organic Soils in Malaysia. In: Tropical Peat, Aminuddin B.Y. (Ed.). MARDI, Malaysia, ISBN: 9679361276, pp: 107-113.

Tie, Y.L., 1988. Report on a Semi-detailed soil survey of the Sibu-Bintangor Deep Peat Area. Sibu/Sarikei Division. Report No. 260. Soil Division. Research Branch, Department of Agriculture, Sarawak. 